Arab World English Journal (AWEJ) Volume 12. Number2 June 2021

DOI: https://dx.doi.org/10.24093/awej/vol12no2.23

Pp.330-347

\title{
Literature in the Algerian EFL Bachelor of Arts degree: Reading Literature
}

\author{
Yamina BELAL \\ Department of English, Faculty of Foreign Languages \\ Mohamed Ben Ahmed University \\ Oran, Algeria \\ Ghania Ouahmiche \\ Department of English, Faculty of Foreign Languages \\ Mohamed Ben Ahmed University \\ Oran, Algeria
}

Received: $1 / 13 / 2021$

Accepted: 5/31/2021

Published: 6/24/2021

\section{Abstract}

Given the acknowledged and undeniable advantages of literature in language education, it has been integrated into EFL curricula for undergraduate students as an essential subject. In the Algerian English departments before the reform introduced in the last two decades (the Licence, Master, doctorate system), literature used to have a privileged status in terms of the number of courses and number of classes or tutorials. However, after the reform, the importance of literature and the lion's share that it used to have in the EFL Bachelor of Arts course regressed in favor of more specialized subjects. Such a reform has only worsened the state of the art of EFL literature teaching, which was already in a deplored state according to the will be cited studies. This article aims at pointing at the primary defects or malfunctioning of the first-year literature course by answering the question: what are the main flaws of the first-year EFL literature course? In order to answer this question, the article starts with a review of the whole literature course package, i.e., objective, content, methodology, and assessment. More importantly, to go beyond mere evaluation and criticism, the article ends by suggesting an alternative course that adopts task-based language teaching as a methodology. The proposed task-based literature course attempts to overcome the observed weaknesses or the inefficiencies of the actual course by matching the course objective, content, methodology, and assessment to students' needs and aptitudes.

Keywords: EFL learners, EFL literature course, language proficiency, literary competence, taskbased language teaching

Cite as: BELAL, Y., \& Ouahmiche, G. (2021). Literature in the Algerian EFL Bachelor of Arts Degree: Reading about Literature or Reading literature, the Relevance of the Task-Based Approach in Teaching Literature. Arab World English Journal, 12 (2) 330-347.

DOI: https://dx.doi.org/10.24093/awej/vol12no2.23 


\section{Introduction}

Literature has always been a companion to language teaching ever since introducing this art or this science in the world. This trend started in the $19^{\text {th }}$ century with the grammar-translation method. In those days the means and the main objectives of learning languages were to understand and translate literary texts in the target language (Hall, 2000).Nowadays, the postmethod and digital era, literature remains crucial in language teaching, and it is being used in the form of movies and audio-books shared by students and teachers.

All over the world, faculties of languages and faculties of literature are joined to each other and are named faculties of languages and literature. This implies that students who choose to learn a foreign language have to study its literature. The reason behind this intrinsic relationship between language and literature is to be found in the nature of each of them. Brumfit and Carter (1986) assume that there is no distinction between the literary language and the non-literary one and that literature only represents samples from real-life language. In other words, literature and language represent the two sides of the same coin. For the reason that language is the main medium of literature to express high-valued meaning and messages; on the other hand, literature is the shop window through which a language exhibits its samples of beauty. No wonder then that literature serves language learning and has always been part of language learning curricula for decades.

However, it is worth noting that at one time in history, there was a slight regression of the role of literature in language teaching. The high level of exchange between nations created an urgent need to communicate effectively; consequently, language teaching started to be more concerned with real-life communication. There was no time for extended literary texts or even for beautiful poems. The rise of structural and notional-functional syllabuses was the main mark of this period in English Language Teaching (ELT). ( Tarvin\& Al-Arishi, 1990).

When Communicative Language Teaching (CLT) came to the front scene of language teaching in the 1980's, the search for authentic materials and genuine communication started. This search led directly to literature that reintegrated language teaching with force. Several CLT researchers argue for the use of literature in ELT (Duff\&Maley, 2003; Lazar, 1993; Widdowson, 1975). Among the arguments for the benefits of literature in language teaching, Lazar (1993) stated that literature can help students in promoting their language skills and developing their overall language proficiency; it helps students develop their academic literacy and critical thinking skills; it is authentic and motivating materials; and it encourages cultural understanding.

Nowadays, in the post-method era, the question is not on whether to teach literature or not in EFL curricula but on how to teach it effectively to gain the assumed benefits. These, unfortunately, are far from being achieved in the EFL literature classrooms around the world. The reasons for this gap between the theoretical assumed benefits and the reality of literature teaching are diverse. For example, Bisong (1995) observes that in Nigeria and in the absence of a "systematic training in how to read literary works" (p. 291), students make use of study guides and notes called lectures' 'handouts.' Similarly, in Norway, Wiland (2009) notes, "teachers and textbooks sabotage the aesthetic reading by introducing exercises and questions that are incompatible with the aesthetic reading attitude"(p. 2). In Algeria, Miliani (2003) compares the 
situation of literature teaching to that of "a king in rags" in an allusion to the paradoxical and contradictory status of literature in EFL situations.

Indeed, a lot has been said and written about literature teaching in EFL context for decades. Notably, in recent years, the topic has been the concern of several Algerian teachers and researchers. For instance, as students and teacher researchers, the authors of the present article have always wondered about the discrepancy between the assumed theoretical benefits of literature teaching and its dramatic reality. Having been a student in the classical four-year Bachelor of Arts degree, one of the authors of this paper could not understand why second-year students had to read Chaucer and Shakespeare's King Lear which she couldn't understand. In contrast, the same students in the third year read relatively easy short stories like Eveline by James Joyce.

Inspired by these anecdotal remarks as well as on the vast amount of literature on the topic, the authors of the present paper do not aim to reiterate what has already been observed and written, but rather to systematically review it to pinpoint accurately the deficient areas that cause the plight of literature in the Algerian EFL departments. More importantly, the paper attempts to go beyond mere criticism to propose an alternative approach to teaching literature. This approach is embodied in a task-based literature course which is likely to remedy the observed deficiencies of the present literature syllabus. But before delving into the details of the actual and the proposed literature course, an overview of literature teaching in the Algerian EFL course at the tertiary level is presented.

\section{Literature Review: Literature in the Algerian EFL Bachelor of Arts Degree before and after the Reform}

After passing the baccalaureate, the Algerian national diploma of secondary education, the students who choose to major in English as a foreign language come to university with a language proficiency level that varies between elementary and intermediate after studying English for seven school years. Before the reform introduced in the Algerian higher educational system, namely the Licence, Master, Doctorate named L.M.D system, these students confronted a four-year Bachelor of Arts (B.A.) course in which the subject of literature had the lion's share. Within this higher education architecture, which is now known as 'the classical system,' students had a course in English literature, a course in American literature, and one in African literature. Each of these courses was studied for one hour and a half session a week, which made the total of four and a half hours of literature taught a week in the third and the fourth year.

However, the study of literature was postponed till the second year; in other words, firstyear students used to study only the essential language skills. This situation was in line with structuralism in language teaching, wherein mastery of the language preceded the academic study of literature. The argument was: "If students' language is inadequate, then let them follow an intensive preparatory course of the language study in their first year (...) only then should they face the terror of "real literature"” (Brumfit, 1983, p.2).

Indeed, our Algerian EFL students did face the "terror" of "real literature" since the second year literature syllabus was divided into two courses: the English literature course and the American literature course. Each of these courses contained canonical literary texts graded 
following the chronological evolution of literature and literary movements. Thus, second-year students in the classical four-year B.A degree had to read Chaucer, Milton, and Shakespeare in the English literature course. Also, they had to read excerpts from Of Plymouth Plantation, and Thomas Pain's Common Sense (see appendix A). The thing that was not self-evident for those students who though completed the first academic year, their language proficiency and their reading experience could not enable them to read, interact, and appreciate such canonical old works. In fact, the rate of failure recorded in literature exams clearly revealed students' difficulties and lack of motivation in coping with that course. For example, in a study carried out at Algiers University, Belal (2012) reported that the rate of failure in literature exams in the second year during the academic year 2009/2010 was ninety-five percent $95 \%$.

The reasons behind this situation, according to some Algerian professors and teachers, are multiple. For example, Miliani (2003) observed that students were almost illiterate in the domain of literature which showed the decline of the popularity of the subject among the students. According to him, this may be due to the learners themselves, but there might be other causes. Similarly, Bensemanne (2004) noticed that certain teaching practices inhibited the personal thought and suggestions inspired by the literary text, which had consisted the core of literary analysis. In other words, Bensemanne put into question the way of teaching literature that had prevented the interaction between the literary text and the learner. Did the reform bring some changes to this situation?

The reform introduced between 2006 and 2008 in the Algerian higher education came in the aim of modernizing the Algerian university and upgrading the courses taught. One of its significant changes was the shortening of the B.A. course into three years instead of four, and so it made it specialized and more focused on practical knowledge and subjects. Therefore, in the English as a foreign language B.A. course, literature moved down to a secondary position in favor of subjects like English for Specific Purposes (ESP) and Information Technology (IT).

Given the shorter time, the LMD students need to get acquainted with literature as soon as they start their university studies. In other words, the study of literature is not postponed till the second year as in the classical system, but it is programmed in the first year under the course title: "Initiation to Anglophone literature." As the name suggests, the course is no longer fractioned into American literature, English literature, and African literature courses as the was the practice in the classical system. Still, it is supposed to include samples of each literature. Yet, the teaching sessions and time allocated to literature have shrunk considerably from three hours in the second year to an hour and a half per week only. Surprisingly, despite the limited teaching time, the supposed condensed content, and the moderate language proficiency level of the firstyear students, the initiation to literature course continues to include similar content to that of the second-year classical B.A. English literature course (appendix A). To put it in another way, the freshman undergraduate students have to meet and read "canonized texts which belong to former centuries" (Djafri, 2012, p.109).

As far as the methodology of teaching, that is to say, the teaching techniques of literature within the reform, i.e. in the LMD system, Kheladi (2013) sums up the situation observing: "literature teaching is still regretfully "chalk and talk" practice" (p.94). In another study at the 
University of Ouargla (South Algeria), Benzoukh \& Keskes (2016) reported that teachers and students are disappointed and unsatisfied with the literature course.

Inevitably, these remarks lead to conclude that, unfortunately, the reform did not bring any change to literature teaching except reducing its teaching time. In what follows, the causes of this dissatisfaction or the main weaknesses of the EFL Algerian literature course will be pointed at by reporting on studies and research carried out in different universities in the country.

\section{The main flaws of the Initial Literature Course}

Since any course, according to Nunan (1990), is made up of course objectives, course content, methodology, and assessment, each of these four elements in the literature course (in the classical system and the LMD) is looked at and assessed to highlight the shortcomings and the strengths of each of them.

\section{Objectives of the Initial literature course}

Several educators (Brumfit\&Carter, 1986; Hall, 2005; Hirvela,1996; Lazar,1993) hold that the main objective of teaching literature, whether in the native language or a foreign language, is to raise students' aesthetic awareness of literature, or to develop what Culler (1975) calls "literary competence." In addition to this primary objective, secondary objectives may include: develop student's language awareness, enrich their cultural understanding, and build their critical thinking.

In contrast, when reading the Algerian literature course, one may realize that the course objectives are stated vaguely. The overall aim of the course is absent; besides, the kind of skills and competencies, which students should acquire by the end of the course, are not highlighted. For example, in the classical four-year B.A. degree, the objectives of the English literature course are stated as follows: "The aim of the course is to provide the students with a general survey in English literature from Chaucer to Blake with an extensive view" (see appendix A). Literally, this would imply that by the end of the course, students should have extensive knowledge about the different authors and literary texts, which have marked the literary scene in a given period, here for example, from the end of the fifteenth century to the end of the sixteen century. To put it differently, students at the end of the course should have read about the historical evolution of literature and known its prominent authors.

It might be argued that the course objectives were intentionally left vague to allow teachers some freedom in interpreting them according to their understanding of literature teaching. For example, Belal (2012) finds that literature teachers consider developing in the students the skill of reading and appreciating literature more important than providing them with an overview about the literary movements and their authors. Despite this awareness of the main objective of literature teaching, the content of the course dictated by the central administration restricts these teachers in the literature classroom. Besides, according to Benzoukh \& Keskes (2016), many of these literature teachers lack the methodological knowledge to help their students with the skills of literature.

\section{The Initial Literature Course Content}

Quite expectedly, the selected content of the course matches the course's stated objectives. Therefore, in the classical second-year literature course as in "Initiation to Anglophone 
Literature" of the L.M.D. system, the selected literary works include Chaucer, Shakespeare, Milton, Pope, Defoe, Richardson, and American writings of the colonial and the revolutionary period (appendices A and B). Djafri (2012) observes: "Algerian syllabus designers seem to favor a chronological arrangement which provides a historical satisfactory perspective thinking that it best suits the students 'way" (p.61).

Confronted with such canonical old literary texts, which might present some difficulties even to English speakers, Algerian EFL students ended up reading about the selected literary texts i.e., students read synopsis of the texts, biographies and critical reviews rather than the literary texts themselves. For how can EFL students who are still struggling to process the grammar of the language read and understand Middle English literature? In fact, these students do not possess the language proficiency and the reading experience which allow them to read and interact with these selected texts. Nor do they find these texts appealing to their interest. In this line of thought, Djafri (2012) contends:

The experience has shown that the response and the interaction with a contemporary novel or poem that often offers elements of identification is quite different from a response to a metaphysical 17 th-century poem by John Donne whose complexity of structure and idea may not be understood at all (p. 62)

In sum, the content of that course was selected to suit the objective of reading about literature rather than reading, interacting, and responding to literature.

\section{Methodology of Teaching in the initial Literature course}

To solve this unequal equation (on the one side students' limited language proficiency in all skills including reading, and canonical, old literary texts on the other side), teachers of literature resort to one teaching methodology, namely, explaining every bit and piece about the literary text (Belal, 2012; Fehaima, 2017; Kheladi, 2013). To put it differently, teachers of literature in our English departments follow a teacher-centered approach wherein they do everything with the literary text, and students have only to listen and take notes. A state of fact confirmed in several studies, for example, after interviewing teachers of literature in the department of English in Tlemcen, Fehaima (2017) finds that most of them "utilize talking and explaining "facts" about literature texts to the students"(p.61). Likewise, Belal (2012) finds that most of the teachers of literature in the department of English in Algiers say that they use lecturing and explaining to the students during most of the class time. On his part, Miliani (2003) compares these classes to a "one-man show, where the narcissist teacher is only intent on listening to himself" (p.46).

This methodological choice may not only be due to students' incompatible proficiency level with the content, as the teachers presume. It is also due to teachers' lack of training and updating in teaching techniques and methodology. This is confirmed in a research by Benzoukh \& Keskes (2016). The research conducted at the University of Ouargla( south Algeria) found that the teachers interviewed neither had any training on teaching literature, nor did they have knowledge about the different approaches of teaching, and they were not even aware of which teaching strategy they used in analyzing literary texts. In turn, this stems to the fact that most teachers of literature in our English departments majored in literature and cultural studies and had little knowledge about English Language Teaching (ELT). 


\section{Assessment in the initial literature course}

Assessment is an integral part of any course since it is the way in which we know whether a course or a teaching programme has attained its objectives or not. Therefore, it should obviously follow the course's stated objectives and test what the course has purported to achieve in the students. It follows that if the literature course objectives are to: "provide students with a general survey in English literature from Chaucer to Blake with an extensive view" (see appendix A), then the literature test should test and finds out whether students have obtained this survey or this knowledge. In other words, the test questions should be relevant to the course's stated objectives and test students' knowledge about the literary movements or periods. Paradoxically, teachers design tests that match their understanding of literature teaching objectives, so students receive essay writing questions that measure their ability to comprehend, analyze, and give opinions. These are the core skills of literature that the teachers never trained them to do in their classes.

Conversely, all these students had to do in their literature classes was merely to listen and take notes, as mentioned above, which left them with such a considerable amount of information about literary texts, their authors, and literary movements. In addition, having been used to Freire's (1972) "bank of education" during all their educational process, these students ended up memorizing all this information to get ready for their literature exams. Belal(2012) found that more than 50 percent of the students involved in her study said that they rote learned teachers' lectures to prepare for their literature exams; only seven out of thirty students said they relied on their understanding. Unsurprisingly, despite the effort made, most of these students failed these literature exams (the failure rate is mentioned above). The reasons for this massive failure, according to the teachers, are students' overreliance on memory, their insufficient knowledge of the language, and their misunderstanding of the exam questions (Benzoukh\&Keskes, 2016).

The students, on the other hand, kept wondering about what was expected of them in literature exams. In fact, many of them contested how they were evaluated and thought they deserved better marks than the received ones. (Belal, 2012). The teachers, on their part, kept complaining about students' misunderstandings and inappropriate educational levels.

All in all, there seems to be an incongruence between the literature course's stated objectives, teachers' interpretation of these objectives, the course content, methodology of teaching, and ways of assessment. In brief, there is an urgent need to review the whole course package to make it meet the expectations of both the teachers and the students.

\section{The Suggested Task-Based Literature Course}

To overcome these shortcomings and weaknesses and draw our students' attention to the pages of the literary texts themselves rather than their synopsis and critic's reviews, CLT, with its focus on learner-centeredness, seems to provide the perfect answer. More precisely, TBLT, which is by excellence a learner-centered methodology, is likely to be relevant to teaching literature to freshman undergraduate EFL students. This teaching technique, which consists of organizing the content of teaching around tasks, is susceptible to involving the students in their learning process and so raises their language proficiency and literary competence. 
The idea of organizing the literature content or classes around tasks is not new; decades ago, teachers and researchers such as Collie and Slater (1989), Knuston (1993), Lazar (1993), and Paran (2010) ( to cite but a few) argued for the relevance of such an approach for teaching literature in EFL classes. However, Most of literature teachers in Algerian universities do not adopt this approach in their classes, according to research (Belal,2012; Benzoukh\&Keskes,2016; Fehaima,2017). They seemed either unaware of such an approach or might be reluctant to use a methodology considered more relevant to language teaching than literature as content. What is suggested in using such an approach is not to convert the literature classes into language classes, but it is rather to bridge the gap between language and literature. To this end, the course need to combine literary objectives with literary ones. This, in turn, involves restating the course objectives, reviewing and adapting the content, methodology, and assessment as follows:

\section{Objectives of the Task-based Literature Course}

As far as the objectives are concerned, course designers and teachers need to remember that the course is intended for EFL learners and not for native speakers of the language. As a result, language aims and content aims need to be integrated; in another way, the course should have a two-fold objective. The first one is to increase first-year students' aesthetic awareness of literature (Hall, 2005; Hirvela, 1996) i.e., to develop in students what Culler (1975) calls "literary competence" or a reaction or "a response" to the literary texts according to Brumfit \& Carter (1986). The second objective, which is integrated into the first one, is to increase students' language proficiency.

Since both of these competencies, i.e., literary competence and language proficiency or communicative competence, are achieved through a process and learners go through multiple levels in both of these competencies, it is essential to identify the actual level of the students in each of these competencies via placement tests and questionnaires at the outset of the course. Such identification will enable course designers to highlight the primary skills and sub-skills in the target level, i.e., the level that the course intends to achieve in both literary competence (LC) and language proficiency.

In addition to these two main objectives, secondary or subsidiary objectives are promote students' cultural understanding, develop their reading skills, and develop their critical thinking skills. In order to attend all of these objectives, the course content, methodology of teaching, and mode of assessment need to be reconsidered and adapted to serve the attainment of these objectives.

\section{Content of the Suggested Task-based Course}

Obviously, raising student's literary competence and language ability is unlikely to be attained by old canonical texts which neither match students' proficiency level nor their interest, as it was reported by Djafri (2013). Therefore, instead of following the chronological and historical evolution of British and American literature, content selection should fulfill two main conditions: First, the selected texts ought to be accessible to the students. More precisely, the chosen texts should be within "the threshold of linguistic knowledge" of the students (Alderson, 1984, p.4) that is linguistically challenging but not overwhelming. Second, it should be appealing to the students, put in another way the themes and the topics of the literary texts selected ought to be of interest to the students or in which they can find elements of identification. 
In addition, to end with Friere's (1972) notion of "bank of education" and dichotomy "teacher- learner," students could be involved in the selection of the content. Though some teachers and educators might argue that students do not possess sufficient knowledge about literary texts to involve them in the selection, students may participate in content selection via interviews, class debates, and even questionnaires. During this process, students select the themes appealing to them out of a given list of themes and titles. As a matter of fact, in a study conducted at the University of Oran, Belal\& Ouahmiche (2020) showed that first-year EFL students did have some knowledge about literary texts and suggested several titles. By involving students in the selection of the literary texts, course designers will ensure, to some extent that students are reading interesting and involving texts, and so the students will be motivated to read them all and to issue opinions or responses.

Another essential criterion to consider in content selection, if we are to achieve both literary competence and linguistic competence progressively, is the length of the literary texts. Duff \& Maley (2003) diagnose four difficulties in teaching literature for EFL at the tertiary level, and one of these difficulties is text length difficulty. Indeed, the longer the text is, the less likely students will read it in its integrity. Course designers and teachers need to bear in mind that these students are in an oral society where "reading is the least of students' worries" (Miliani, 2003, p.43), so developing this skill should start with relatively shorter texts. That is why it is recommended that short stories, fables, and fairy tales should be the main literary genre selected for first-year students, then move progressively to novellas and novels.

After laying the guidelines for selecting the task-based literature course content, the following question concerns the way it will be introduced and taught, that is to say, the methodology of teaching.

\section{The Task-Based Language Teaching Methodology}

Perhaps the most pervasive aspect of the alternative course suggested here is the methodological aspect, namely, the task-based methodology. The idea of TBLT is to organize the language teaching content into a series of tasks. It was Prabhu (1987) and Long \& Crookes (1992) who first brought forward this idea. They suggested that if we were to follow the process of language learning, which was found to be rather holistic and consisted of transitional sequences, the content of language teaching should be specified in terms of holistic units, i.e., tasks. Just like language, literature is better seen as a set of skills and competencies than as a body of knowledge to be received from the teacher. In this sense, Brumfit \& Carter (1986) argue that "no teacher teaches directly and deliberately anything worthwhile, teachers simply create conditions for successful learning" (p.23). One of these conditions could be carefully designed tasks around literary texts. Such tasks are likely to engage the students with the literary texts and raise their aesthetic awareness as well as their language proficiency.

Broadly speaking, this methodology consists of dividing the study of any literary text into three sequences; each sequence includes several tasks. First, the pre-reading phase, which precedes the reading of the literary text, serves as an introduction to the study of the text. Second, the while reading sequence, which follows introducing the text; it involves students in performing tasks while they are reading. Third, the post-reading sequence comes after reading 
the literary texts. Each of these sequences has some aims and includes several communicative tasks that we will see in detail.

\section{Pre-reading Tasks}

According to Knutson (1993), these tasks aim to activate the background knowledge with its various kinds (world knowledge, linguistic code, and genre knowledge). This stage epitomizes the content-based approach to teaching literature because it deals with the background knowledge of the literary text, except that here students perform tasks to obtain the information by themselves rather than by listening to the teachers and taking notes.

Among the tasks used in this stage are information exchange tasks or jigsaw activities. The procedure consists of dividing the class into two groups and giving each group a text to read. One text contains biographical information about the author, whereas the other includes the social and historical context of the era of the text. After reading the texts and answering some questions about them, students from each of the two groups are paired up to exchange information about their texts, with the teacher's supervision, of course. In this way, the sociocultural background of the text is introduced, and students' schemata are activated with very little intervention from the teacher. Other tasks in this stage include prediction tasks, and linguistic activities, which involve matching the difficult words in the text with their dictionary definitions.

\section{While-Reading Tasks}

During this stage, students perform tasks while reading the literary text. The first objective of these tasks is to get students to have close attention to the language of the text so that they can realize how the language serves the literary purpose. The second objective relates to metacognition and consists of making the students activate their metacognitive strategies of control to monitor their reading comprehension.

Among the tasks used in this phase, graphic or advance organizers like charts, semantic webs, Venn diagrams, storyboards, matrices. According to Sasser (1992), the use of these organizers is likely to engage students with meaning as the act of filling in requires critical thinking skills. Instead of teachers or lecturers presenting the elements of fiction, which are also elements of literary competence (Culler, 1975), students can build their knowledge of characters, plot, setting, conflict, and themes by filling in these graphic and advance organizers.

For example, to study characters, we can design a chart containing a column with the characters' names and another with the adjectives that describe them. Students then read and highlight in the text the adjectives then fill in the chart. They could reword these descriptions and add their own opinion to write characters' profile. Similarly, the plot or the different elements of the plot could be represented in a chart that students have to complete (see appendix $\mathrm{C}$ ).

Reading logs is yet another task that seeks to raise students' awareness of their metacognitive strategies of reading. The technique consists of asking students to make entries in reading logs by answering some guiding questions while reading. Then students compare their entries and answers in groups (Carlisle, 2000). The list of tasks in this stage is endless; teachers 
can refer to Collie \& Slater (1989) and Lazar (1991) to design tasks suitable for the literary text studied and for their students.

\section{Post-reading Tasks}

This stage serves to extend students' appreciation and to deepen their understanding of the literary work. It is also a synthesis stage which permits students to appreciate the literary text as a whole after a stage where it was segmented into episodes (Harper, 1988)

The tasks that can be designed and performed in this stage include genre transfer, rewriting from a different point of view, comparing the literary text with its film version, continue the story and topic development, or essay writing.

For example, genre transfer consists of asking students to write the literary work in another genre, for instance, rewrite the story in the form of dialogues or a play, and then roleplay it. Another task is to ask students in pairs or in groups to rewrite a significant episode of the story from another character's point of view (McKay, 2001). An alternative post-reading task is comparing the literary text with its film version. As the name indicates, this task consists of asking students to write an essay or give a presentation about the similarities and differences between the literary text and its film version. Continue the story is simply to ask students to imagine an event or other events after the end of the story. Last but not least, topic development is a kind of training for the exam as students work in groups or in pairs to discuss and develop potential exam essay questions. (Baurain, 2007).

\section{Assessment in the Task-based Literature Course}

Assessing literature or literary competence is not a simple and straightforward procedure though, in educational settings, it has been left to the common sense of the teacher. Hanauer (1996) asserts: "From historical point of view, the field of literature does not have a tradition of systematic test construction or evaluation. Yet, nearly all literature courses from primary school to university literary education are evaluated using some sort of exams" (p. 143)

Unfortunately, the exams designed by the teachers in the Algerian literature course cultivated failure and literally led to a conflicting situation between the teacher and the students for the reasons mentioned above.

To remedy this situation, the LMD system introduced continuous assessment, and so a mark for continuous assessment has to go with that of summative assessment. For reasons of practicality, teachers resort to short quizzes and tests for a mark of continuous assessment; a practice that goes counter the essence of continuous assessment, whose main objective is to measure students' progress at different periods.

Given that task-based teaching is a process-oriented approach, continuous assessment seems not only relevant but also practical for assessing students' progress in acquiring both literary competence and language proficiency, which both develop through a process. In this sense, Nunan (2004) argues: "practically any pedagogical task can be used for assessing learner progress" (p.154). The condition that Nunan (2004) puts to use tasks for evaluation is that teachers should lay the assessment criteria upon which they design observation schedules or 
rating scales. A condition that seems rather relevant for the task-based literature course since the course objectives in terms of literary competence and language proficiency were specified at the outset.

As far as summative assessment is concerned, instead of exam questions that foster in the students a habit of memorizing, Carter and Long (1990) proposed language-based question types that drew careful attention to the language of the text and extended to discourse-level activities such as inferring and the application of personal and cultural knowledge. An example of such tests is to ask students to attempt a prose version of a poem or to present students with two versions of a literary text and ask them to determine which one is the original by paying close attention to choices in language. Preferably questions that students had already been trained to answer during the lessons should be selected.

In this way, we can say that we assess students' ability to read literature rather than their knowledge about literature and make sure that the students had been equally and fairly assessed.

\section{Conclusion}

This article has attempted to review literature teaching in the EFL Algerian curriculum at the tertiary level. It demonstrated that the course as it is taught before and after the LMD reform suffers from a number of deficiencies in all its areas. More precisely, it appeared that there was a mismatch or incongruence between the course stated objectives, the course content, methodology of teaching, and assessment. Such state of fact had diverted the course from teaching how to read, enjoy, and react to literature to read about literature and memorize lectures and facts for the sake of exams. This, in turn, led to students' frustration and teachers 'dissatisfaction.

Such findings implied that the whole literature course needed to be reviewed, which came in the suggested task-based literature course. In this course, the student's needs and abilities serve as a reference in setting course objectives, content, methodology, and assessment. The most pervasive changes in this course are adapting the content to students' aptitudes and abilities and involving theses students in their learning by asking them to perform tasks.

Several teachers and researchers (Baurain, 2007; Carlisle, 2000) experienced the use of tasks in literature classes for EFL undergraduate students and reported the positive effect of such tasks for both literary competence and language proficiency. Whether the same effect will be noted in the Algerian context or not is a question to be answered in further research.

What is left to be done, however, is to convince decision-makers, curriculum designers as well as teachers and educators of the necessity of first, taking into account learners' needs, aptitude and interest while designing courses and syllabuses, particularly literature ones and second involving them in the learning process. Experience has shown that only in this way revolution in education happens.

\section{About the authors}

Yamina Belal is a teacher and a Ph.D. researcher at Mohamed Ben Ahmed University, Oran2, Algeria. She specializes in language and literacy education. Her research interests include 
course and material design for EFL students, literature teaching and literary competence, reading in EFL and reading strategies. https://orcid.org/0000-0001-5442-7091

Ghania Ouahmiche is a senior lecturer and researcher at Mohamed Ben Ahmed University. She is an author and a co-author of a number of articles. Her research areas include: applied linguistics, ELT teaching methodology in Algeria, sociolinguistics, and others.

https://orcid.org/0000-0002-1743-664X

\section{References}

Alderson, J.C. (1984). Reading in a foreign Language: a reading problem or a language problem? In J. Alderson \& A. H. Urquhart (Eds.), Reading in a foreign Language (pp.1-24) London: Longman.

Baurain, B. (2007). Small Group Multitasking in Literature Classes.ELT Journal 61(3),237-245 Belal,Y.(2012). Designing a Task-Based Literature Course for Second Year University Students,(Unpublished Magister dissertation). University of Algiers, Algeria.

Belal,Y.\& Ouahmiche, G.(2020).Investigating the Literary Competence of Freshman EFL students at Mohamed Ben Ahmed University. Asian Journal of Educational Research. 8(1) available at http://www.multidisciplinaryjournals.com

Bensemmane, M. (2004).A De-Centred Approach to Teaching Literature. Lettre de Kairawan, 4, 7-13

Benzoukh, H. \& Keskes, S. (2016). EFL Teachers' Attitudes towards the Literature Courses Taught at the English Language Department of Kasdi Merbah University- Ouargla. ElAthar Magazine, 25, 27-35.Available at http://www. Researchgate.net/publication/317553134

Bisong, J.O. (1995). An Approach to the Teaching and Learning of Poetry in Nigeria. In G.Cook \& B. Seidlhofer (Eds.), Principles and Practice in Applied Linguistics (pp.289302).Oxford: Oxford University Press.

Brumfit, C.J. (ed.). (1983). Teaching Literature Overseas: Language-Based Approaches, ELT Documents 115. Great Britain: Redwood Burn ltd.

Brumfit, C.J.\& Carter, R. A.(Eds.) (1986).Literature and Language Teachin.Oxford: Oxford University Press.

Carlisle, A. (2000). Reading Logs: an Application of Reader-Response Theory in ELT. ELT Journal,54(1), 12-19 .DOI, 10.1093/elt/54.1.12

Carter, R. \&Long, M. (1990). Testing Literature in EFL Classes: Tradition and Innovation. ELT Journal,44(3),215-221.DOI,10.1093/elt/44.3.215

Collie, J. \& Slater, S. (1987). Literature in the Language Classroom: A Resource Book of Ideas and Activities. Cambridge: Cambridge University Press.

Culler, J. ( 1975). Structuralist Poetic. London: Routledge.

Djafri,Y.(2012). Innovation vs. Canonisation: Foreign Literature Content in the Algerian Degree of English.El-Tawassol: Langues, Culture et Littérature,31,58-70

Djafri, Y. (2013). Great texts and Literary Appreciation: an Algerian University Experiment. In I.Ahmed Elsherif \& P.M. Smith, (Eds.), Adventuring in the Englishes: Language and Literature in a Postcolonial Globalized World (pp.109-114). United Kingdom, Newcastle: Cambridge Scholars Publishing.

Duff, A.\& Maley, A.(2003).Literature. NY-China-Oxford: Oxford University Press 
Fehaima, A. (2017). EFL Learners' Responses and Attitudes towards Literary texts: the Algerian Context. European Journal of Research in Social Sciences, 5(3),58-62 available at http://www.idpublications.org

Friere, P. (1972). Pedagogy of the Oppressed. England: Penguin Books Ltd.

Kheladi, M. G. (2013). Investigating EFL Learners Attitudes towards Literature Teaching Methods: The Case of $2^{\text {nd }}$ Year L.M.D. Students at the University of Tlemcen,(Unpublished Magister dissertation). University of Tlemcen, Algeria.

Hall, G. (2005). Literature in Language Education. New York: Palgrave Macmillan

Hanauer, D. (1996). Academic Literary Competence Testing. Journal of Literary Semantics. 25(2), 142-153

Harper, S.N. (1988).Strategies for Teaching Literature at the Undergraduate Level.The Modern Language Journal,72(4),402-408

Hirvela, A. (1996).Reader Response Theory and ELT.ELT Journal, 50(2),127-134.DOI, 10.1093/elt/50.2.127

Knutson, E.M. (1993).Teaching whole Texts: Literature and Foreign Language Reading Instruction.The French Review,67(1),12-25

Lazar, G. (1993). Literature and Language Teaching: Guide for Teachers and Trainers. Cambridge: Cambridge University Press.

Long, M. \& Crookes, G.(1992). Three Approaches to Task-Based Syllabus Design. TESOL Quarterly, 26 (1),27-56. DOI, 10.2307/3587368

McKay, S.L. (2001). Literature as Content for ESL/EFL.In M.Celce-Murcia (ed.) Teaching English as a Second Language (pp. 319-332).MA: Heinle and Heinle-Publishers.

Miliani, M. (2003). Literature in an EFL Situation: A King in Rags. In F.Benzaoui, \&M, Miliani, (Eds.) A Multi-Disciplinary Approach to Teaching of Literature. Algeria: Office des Publication Universitères.

Nunan, D. (1990). Research Methods in Language Learning. Cambridge:Cambridge University Press.

Nunan, D. (2004). Task-Based Language Teaching. Cambridge: Cambridge University Press

Paran, A. (2000).Survey Review: Recent books on the Teaching of Literature. ELT Journal, 54(1), 75-88. DOI,10.1093/elt/54.1.75

Prabhu, N.S. (1987). Second Language Pedagogy: A Perspective. Oxford: Oxford University Press

Sasser, A. (1992).Teaching Literature to Language Minority Students. In P. A.Richard-Amato \&M.A. Snow ( Eds.), The Multicultural Classroom: Reading for Content-Area, (pp. 300315).U.S.: Addison-Wesley publishing company.

Tarvin, W.L.\& Al-Arishi, A. L.(1990). Literature in EFL: Communicative Alternatives to Audiolingual Assumptions. Journal of Reading,34(1),30-36.

Widdowson, H.G. (1975). Stylistics and the Teaching of Literature. England: Longman

Wiland, S. M. (2009). How to Develop Literary Competence in the English Classroom.The Norwegian National Centre for Foreign Languages in Education. Available at www.fremmedspraksenteret.no/nor/fremmedspraksenteret/engelsk. 


\section{Appendices \\ Appendix A \\ The Second year Literature course syllabus of the classical Four-year B.A course UNIVERSITY OF ALGIERS \\ FACULTY OF ARTS AND LANGUAGES \\ DEPARTMENT OF ENGLISH \\ ENGLISH DEGREE CURRICULUM}

Semester 03:

General survey of English literature from Chaucer to Blake

The aim of the course is to provide the students with a general survey in English literature from Chaucer to Blake with an extensive view.

The experts will serve as a basis for the study of literary devices (plot, setting, characterization...etc).

1) General introduction

2) Old English and Middle English

3) Elizabethan and Jacobean period (poetry and drama)

4) Milton

5) Pope

6) Defoe

7) Swift

8) Richardson

9) Theatre, Sheridan, Goldsmith

10) W. Blake

\section{Semester 03:}

American literature

Objective of the course: The aim of the course is to provide the students with a general survey from the colonial period to the romantic period. Excerpts from representative texts will serve as a basis for the study of literary devices.

1- The colonial period

Prose: extracts from J. Smith, W. Bradford, J. Edwards.

Poetry: selected poems by Anne Bradstreet, Wiggesworth, E. Taylor (2h)

2- The revolutionary period

Prose: extracts from T. Pain, B. Franklin, Madison, Hamilton (2h)

3- The Romantics

W. Irving: Rip Van Winkle

J.F Cooper : The Spy of the Prairie

N. Hawthorne: The Blithedale Romance or the Celestial Road (2h)

(NB: this document was delivered by the Head of the English department at the university of Algiers in the academic year 2009/2011)

Appendix B

The first Year literature syllabus of the L.M.D. system

Université Mohamed Ben Ahmed, Oran 2

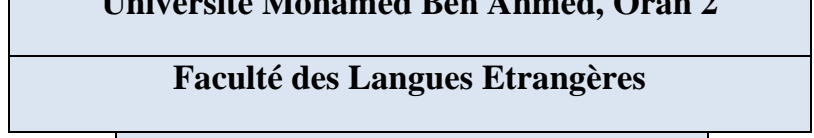

Département : Anglais

Feuille Pédagogique : Programme par matière

Matière : Etude de textes littéraires

«Study of Literary Texts »

Contenu de la matière

Semestre 1

Week 1. Introduction to literature 
- The notion of literature: meaning of literature, its purpose and importance....genres (fiction/nonfiction, prose/verse/drama)...

Week 2. Introduction to literature (continued)

- The notion of literature: what shapes it? Influence of gender/race; Religion and mythology; impact of wars...etc.

Week 3.The elements of fiction ( The 6 majorelements in selected texts)

Week 4. Characters / Plot

Week 5. Setting / Point of view

Week 6. Theme / Style

Week 7. Test

Week 8. Introduction to figurative language

Week 9. Interpreting figures of speech in context

Week 10. Metaphor/ Simile

Week 11. Hyperbole/understatement/ Oxymoron

Week 12. Metonomy/ Synecdoche/ Personification

Week 13. Irony/ Humor/ Personification

Week 14. Exam

Semestre 2

Week 1. Development of English/ Emergence of movements (an overview)

Week 2. Old English Literature (450 AD-1066) : a historical survey

Week 3. Selected Texts/ e.g. Beowulf, Caedmon's Hymn, The Wanderer... and others.

Week 4. Middle English Literature $\left(12^{\text {th }}\right.$ century-1485) : a historical survey

Week 5. Selected Texts/ e.g. Chaucer's The Prologue, Sir Gawain and the Green knight,

Everyman: AMorality Play, and others.

Week 6. The Elizabethan Period/ Renaissance and Reformation (1485-1603): a historical

survey

Week 7. Selected Texts: Shakespeare (and others).

Week 8. The golden age of drama/ Selected plays: The Merchant of Venice, Othello, and

others.

Week 9. Test

Week 10. The Seventeenth Century: a survey

Selected Texts / The Metaphysical School

Week 11. Introduction to Restoration and the $18^{\text {th }}$ century: Neoclassicism and Satire

Week 12. Selected texts/ e.g. John Gay's Trivia, Pope's The Rape of the Lock, Essay on Man,

Dryden'sEpigram on Milton, and others.

Week 13. The rise of the novel (1700's)

Selected texts:/ e.g. Defoe's Robinson Crusoe, Samuel Richardson, and others.

\section{Appendix C}

A Sample Task-Based literature unit for the study of Irving's Rip Van Winkle

Outcome of the unit: By the end of the unit students will have acquired knowledge about the characteristics of Romanticism in literature; they will have developed their reading skills by reading the story fully; they will have analyzed the literary devices and responded personally to the story; and they will have extended their vocabulary and practice their speaking and writing skills.

\section{Lesson1}

\section{I) Pre-reading tasks:}

Objectives: the aim of these tasks is to activate the background and the linguistic knowledge of the students by getting information about romanticism and Irving. Also, the tasks aim to raise their interest in reading.

\section{Stage 1:}

The class is divided into two groups. Group A read an extract about romanticism, and group B read an extract from Washington Irving biography. Then, each group answers the questions below each extract. 
( N.B: Extracts giving information about the Catskill Mountain and the Dutch settlers in New York can be used to activate student's schema knowledge.)

Stage 2: Students from group A join students from group B and in pairs or groups of three to four students exchange information about their articles.

Stage3: In pairs students jot down the themes that can be read in a work of literature written by Irving within the Romantic period and then compare their ideas.

\section{Task2}

The teacher writes on the board the following words:

Rip Van Winkle

Hen-pecked husband

He was thrice blessed

termagant wife meekness of spirit a good-natured fellow

a shrew a strange man

Working in pairs or in groups, students are asked to brainstorm a narrative link between the words to tell a story. Then, in class students compare their stories.

\section{II- While-reading tasks:}

\section{Lesson 02:}

Objective: The aim of this lesson is to give the students a purpose for reading and to sensitise them to the way an author presents a description or a theme. The literary aims include the study of the setting and the characters

Task 01:

Stage 01: students skim through the two first paragraphs and then work in groups. Group A: extract the words and the adjectives that describe the Kaatskill, then put the words under the following headings.

\begin{tabular}{|l|l|l|l|l|}
\hline Colours & Verbs of movement & Clothes & Time & Supernatural/unusual \\
\hline & & & & \\
\hline
\end{tabular}

Locate the mountains in the map of the U.S and draw a picture of the mountains following the description.

Group B: extract words that describe the village then arrange them according to the word category.

Draw a picture of the village following the description.

Stage 02: members of group A pairs up with members of group B and exchange the pictures they draw. They, then, discuss the effect that such a description produce. What does this description lead them to expect from the story? What personification is used for the Kaatskill mountains

Stage 03: Pretend that you are a film director, how would you film the opening setting?

\section{Task 02:}

read the extract from "in that same village... he would fly to the door with yelping precipitation".

Stage 01: Complete the following charts with the adjectives and words that describe Rip, his wife, his dog, his children and his farm.

Chart 01:

\begin{tabular}{|l|l|}
\hline \multicolumn{2}{|c|}{ Rip Van Winkle } \\
\hline The narrator's opinion & \\
\hline $\begin{array}{l}\text { As seen by his neighbours, the } \\
\text { children and the good wives of } \\
\text { the village }\end{array}$ & \\
\hline His wife's opinion & \\
\hline Your own opinion about Rip & \\
\hline
\end{tabular}


Arab World English Journal (AWEJ) Volume 12. Number 2. June 2021

Literature in the Algerian EFL Bachelor of Arts degree

BELAL \& Ouahmiche

\section{Chart 02:}

\begin{tabular}{|l|l|}
\hline \multicolumn{2}{|c|}{ Dame Van Winkle } \\
\hline The narrator's opinion & \\
\hline As seen by her neighbours & \\
\hline Rip's opinion of her & \\
\hline $\begin{array}{l}\text { Your own opinion and ideas of } \\
\text { her }\end{array}$ & \\
\hline
\end{tabular}

Chart 03:

\begin{tabular}{|l|l|}
\hline \multicolumn{2}{|c|}{ Rip's family and possessions } \\
\hline Wolf the dog & \\
\hline His children & \\
\hline His farm & \\
\hline
\end{tabular}

Chart 04: complete the chart by defining the attitudes and relations between the three characters.

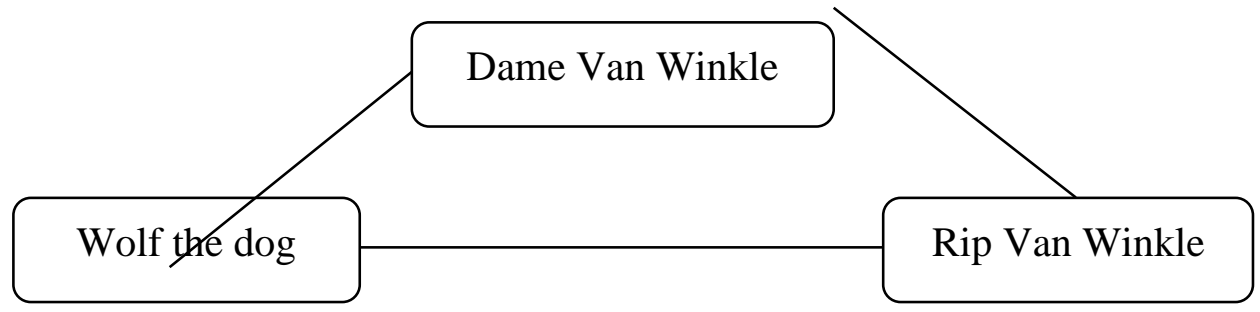

Stage 2: Students write a character profile for each of the characters then compare their answers in pairs and justify them by referring to the language of the text.

Stage 3: Do you know a person like Rip or his wife? What traits do they share with the characters of the story? Do you find anything amusing or funny about the relationship of Rip with his wife? Pick up the words and phrases that arouse amusement.

\section{III) Post reading tasks}

\section{Lesson 3 or 4}

Objectives: the aim of these tasks is to expand students' understanding and appreciation of the short story and to raise their critical thinking by exploiting the themes of the story in creative writing.

Stage 1: Students work in groups and choose one of the following tasks to perform in groups.

Task1: Suppose that you are Rip rewrite what happened to you from the day you went shooting squirrels in the highest part of the Kaatskill Mountains till your return to the village and your gathering with your daughter.

Task2: Retell the story from Dame Winkle point of view.

Task 3: Rip consoled himself by frequenting a group of sage, but he was driven out by his wife. Imagine the scene the scene that might have happened in the inn. Work in groups of three or four students and role play a dialogue between Rip, his wife Dame Van Winkle, and Nicholas Vedder.

Task 5: Romantic heroes are generally childlike, distrustful of women, fond of nature, in search of higher truth, find lines from the story to describe each character trait.

Stage 2: Each group presents the outcome of their task to the class. 